\title{
Service Quality and Customers Preference of Cellular Mobile Service Providers
}

\author{
Rajkumar Paulrajan and Harish Rajkumar ${ }^{\prime}$
}

\begin{abstract}
A research study was conducted with an objective to understand the Indian consumers' perception choice in selecting cellular mobile telecommunication service providers. Consumers' perception is widely varied in accordance with the Communication quality, call service, facilities, price, customer care and service provider's attributes. A structured questionnaire was developed to collect the required primary data from the consumers. Collected data were analysed, reliability and factor analysis were carried out. The outcome of this research shows a comprehensively integrated framework to understand the relationships among several dimensions. The study shows communication and price were most influential and most preferential factors in selecting telecommunication service provider. However, product quality and availability has a significant impact on consumer perception choice in selecting cellular mobile service provider.
\end{abstract}

Keywords: Service quality; cellular; mobile; customer preference.

\footnotetext{
I Institutional affiliation: Department of Industrial Engineering, Anna University, Chennai, India, Contact address : 27 / 6 Bazaar Street, West KK Nagar, Chennai 600 078, India, Phone number : +91 98416 75969, E-mail address: raniha@yahoo.com
} 


\section{Indian Cellular Mobile Service}

In the last ten years, the mobile revolution has truly changed the socio-economic landscape of India and played a pivotal role in the growth and development of the economy. According to Cellular Operator Association of India (COAI), India ranks between the top ten telecom network in the world and the second largest in Asia. India is also one of the fastest growing markets in mobile communications. Telecom Regulatory Authority of India's report on Telecom Services Performance (TRAI, 20I0) indicates cellular mobile subscriber base touching 635.7I million in June 2010. Growth in India's mobile telephone sector has been nothing short of spectacular in the past few years, aided by higher subscriber volumes, lower tariffs and falling handset prices. India is home to a number of global mobile operators working with local companies and mobile market has consistently experienced very high annual growth rates with the continuous decline in tariff.

The mobile sector subscribers India have grown from around 10 million subscribers in the year 2002 to 250.93 million by the end of February 2008. According to Telecom Regulatory Authority of India (TRAI), a total of 8.49 million telephone connections were added during February 2008. The annual growth of mobile cellular services recorded in India during the last few years has been nearly 100 percent, but still, after over a decade of start of mobile services in the country, only 30 percent of the 600 million addressable markets of mobile users in the country of over one billion people have been reached. Today, around eight million new telephone subscribers are being added in India every month. This is mostly in the mobile telephone segment.

The telecommunication sector, especially the mobile phone sector, in India is one of the fastest growing business segments of the country which provide a lot of value addition to the society with it's service and creation of employment opportunities. At present there are fifteen mobile phone operators in the country - Bharti Airtel Limited (Bharti), Reliance Communications Limited (Reliance), Vodafone Essar Limited (Vodafone), Bharat Sanchar Nigam Limited (BSNL)- Government of India owned public sector company, Tata Teleservices Limited (Tata), Idea Cellular Limited (IDEA), Aircel Limited (Aircel), Unitech Wireless Limited (Unitech), Mahanagar Telephone Nigam Limited (MTNL), Sistema Shyam TeleServices Limited (Sistema), Loop Mobile (India) Limited - Formerly BPL
Mobile (Loop Mobile), Videocon Telecommunications Limited (Videocon), S Tel Private Limited (S Tel), Himachal Futuristic Communications Limited (HFCL) and Etisalat DB Telecom Private Limited (Etisalat). All of them compete with each other to grab customers by providing wide range of services. They not only offer basic services of cell phone but also produce other value added services. Along with the normal services all of the operators are now offer internet facilities which enable the subscribers to reach the whole world through internet easily and their services includes prepaid, postpaid, internet, value added services, roaming and devices. Detail of Cellular Mobile subscriber in India is shown in table I and figure I depicts market share of cellular mobile service providers in India.

\begin{tabular}{|l|r|}
\hline Service Provider & $\begin{array}{l}\text { Number of } \\
\text { Subscribers (in } \\
\text { millions) }\end{array}$ \\
\hline B harti & 136.82 \\
\hline Reliance & 110.81 \\
\hline V odafone & 109.06 \\
\hline B SNL & 72.70 \\
\hline Tata & 72.53 \\
\hline IDEA & 68.89 \\
\hline A ircel & 41.68 \\
\hline U nitech & 6.02 \\
\hline M TNL & 5.21 \\
\hline Sistema & 5.10 \\
\hline L oop M obile & 2.93 \\
\hline V ideocon & 1.94 \\
\hline S Tel & 1.33 \\
\hline HFCL & 0.67 \\
\hline E tisalat & 0.02 \\
\hline T otal & 635.71 \\
\hline
\end{tabular}

Table I Cellular Mobile Subscriber as on June 2010 in India/ Source: TRAI (2010) 


\section{Cellular Mobile Market share in India}

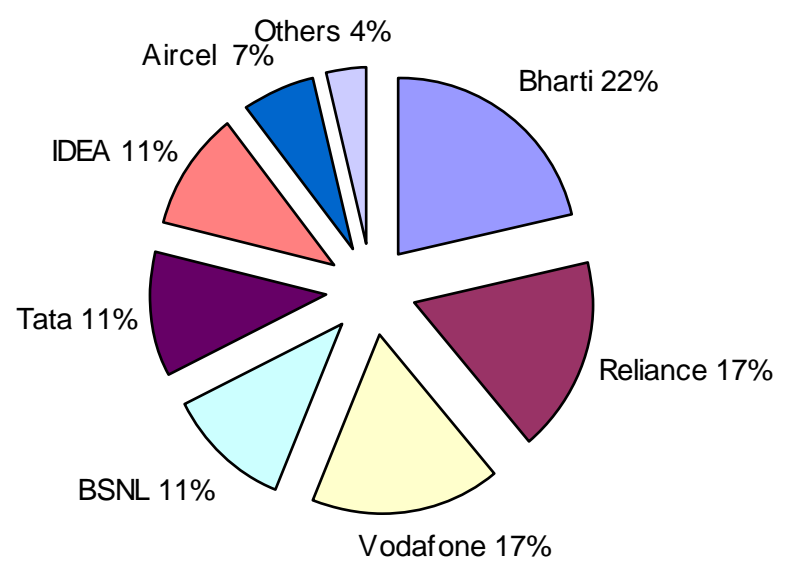

$\square$ Bharti $\square$ Reliance $\square$ Vodafone $\square$ BSNL $\square$ Tata $\square$ IDEA $\square$ Aircel $\square$ Others

Figure I Cellular Mobile Market share in India as on June 2010

The hasty growth and development in information technology and mobile devices has made the Indian mobile phone service markets more and more competitive. It is assumed by all mobile service providers that value added services increases the customer loyalty. But does value added services fulfill all the customer needs and is it the only factor that play a significant role in maintaining and building up the loyalty of the customers. On the other hand according to Lee et al (200I) the mobile providers should build up customer commitment by providing good quality service to their customers.

\section{Service Quality of Cellular Mobile}

The success of telecommunication industry depends on prudent efforts and feasible investments. In a competitive market, service providers are expected to compete on both price and quality of services and also it is necessary for the service providers to meet the consumers' requirements and expectations in price and service quality (Melody, 200I). The positive relationship of service quality with customer satisfaction (Danaher and Mattsson, 1994; Kim et al., 2004), customer preference (Ranaweera and Neely, 2003), profitability (Fornell, 1992; Danaher and Rust, 1996), competitiveness (Rapert and Wren, 1998), is well proven in the academic literature.
Government of India - Department of Telecommunication's data shows that, both BSNL and MTNL are losing market share to private operators in the mobile telephony segment. BSNL and MTNL together are down from a $17 \%$ market share at the beginning of March 2008 to 13.6\% in August 2009. In contrast, the private sector's share jumped from $83 \%$ to $86.4 \%$ during the same period. So the challenge for the mobile service providers in India is to find out the critical factors that influence the customer's preference. Investigators have also found customer satisfaction from a multi dimensional nature and view overall satisfaction as a function of satisfaction with multiple experiences with the service provider. In general satisfaction is developed on the information from all prior experiences with the service supplier and is consider as a function of all prior transaction and information (Parasuraman et al., 2000). Nowadays cellular mobile is a very necessary products for our daily communication. Customers are mainly purchase this product for instant communication and various services provided by the companies. Services mainly depend on some factors and customers are always try to buy that product which has many factors or attributes fulfilling their desire. Recently the concept of customer satisfaction has received much attention. In cellular mobile market, customers bring higher expectations for communication from its service providers and if companies 
are not able to meet these expectations, the customers will take their business elsewhere. The consumers want and expectations are altering all the time, this directs to a condition where customers create ever higher benchmarks. Applying customer satisfaction approach means recognizing customers, and then finding their wants and expectations, and to end with their perceptions. A company's most important success factor is the ability to deliver better customer value than competitors do, and the objective of a strategy is to deliver value to the customers in order to provide required returns to the shareholders and employees (Riggs, 1983). There are many variables and Factors Determinants the Choice of Mobile Service Providers. Haque et al (2010) and Haque and Rahman (2010) benchmark mobile services with the attributes and dimensions illustrated in figure 2:

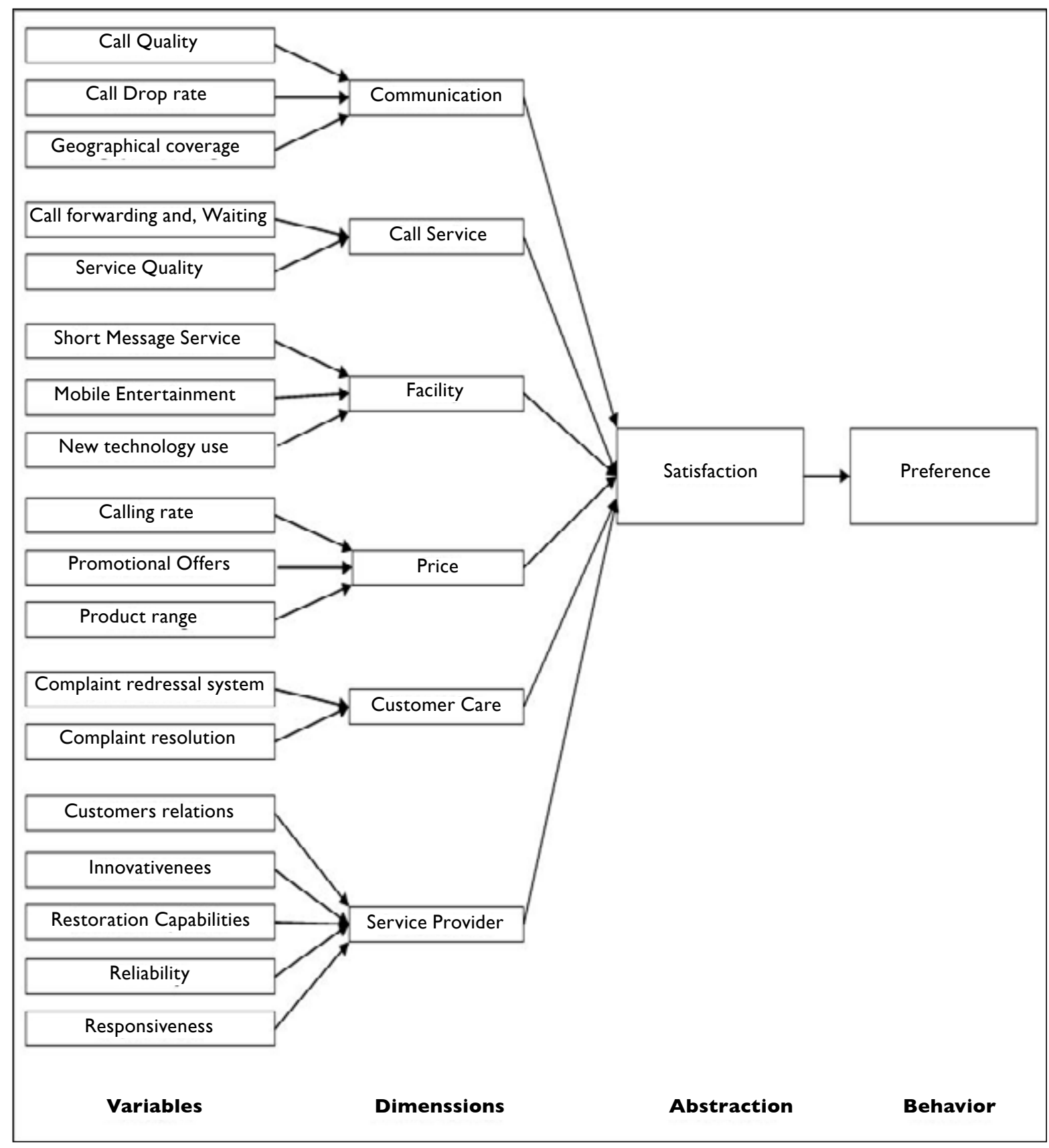

Figure 2 Factors Determinants the Choice of Mobile Service Providers 
J. Technol. Manag Innov. 20II,Volume 6, Issue I

In order to achieve higher levels of quality service in service companies should deliver higher levels of service quality and in the present context customers' perceptions are highest. From the perspective of the service organization, there is a desire to survive and compete in a global environment. From the perspective of the customer, there is a desire for better quality services. In fact the private sector's singular focus is on economic efficiency, as it is generally viewed that profit and/or cost reduction are key ingredients to survival and growth. Service is a form of attitude which is related to satisfaction and also leads to consumer preference and future purchase. In particular consumers prefer service quality when the price and other cost elements are held constant. It has become a distinct and important aspect of the product and service offering. According to Lehtinen and Lehtinen (1991) service quality helps to create the necessary competitive advantage by being an effective differentiating factor Price plays a vital role in telecommunication market especially for the mobile telecommunication service providers. It includes not only the buying price but also the call charges. Generally, a price-dominated mass market leads to customers having more choices and opportunities to compare the pricing structures of diverse service providers. A company that offers lower charges would be able to attract more customers committing themselves to the telephone networks, and, significant number of "call minutes" might be achieved. Consumer's perception of product quality is always an important aspect of a purchasing decision and market behavior. Consumers regularly face the task of estimating product quality under conditions of imperfect knowledge about the underlying attributes of the various product offers with the aid of personal, self-perceived quality criteria.

As competition has been escalating among the corporations, it is ardently necessary for them to learn about the consumers' perception about the communication quality, callservices, facility, price, customercare, service provider's capabilities and other important factors that may have been playing a vital role in selecting the telecommunication service providers. Therefore, the major objective of this study is to cautiously examine the factors that have been affecting the consumers' perception to select mobile telecommunication service, particularly in India.

\section{Research Methodology}

As the major purpose of the study is to understand the consumers' perceptions in the selection of cellular mobile telecommunication service provider in India, a structured questionnaire was developed to collect the required primary data from the consumers. The survey questionnaire consists of six distinct sections, each of which contains relevant questions pertaining different parts of the study. Questionnaires were systematically distributed utilizing a non-probability convenience sampling from walk in customers at market places and educational institutions. The questionnaire was framed in the format of Likert scale to be distributed into the selected sample, and no specific characteristics were defined for the respondents except being a cellular mobile user. The sample, it was logically assumed that the sample represented the whole population of mobile telecommunication services users in India.

A total of 125 questionnaires were distributed and 112 out of them have been completed, implying a response rate of 90 percent. Questionnaire includes five main construct i.e. image, price, quality, customer satisfaction and loyalty. Each construct had three to five questions with an itemized -licker ranking scale of I-5 (I=very poor, 2=poor, 3=average, 4=good, $5=$ =xcellent). All constructs are measured using multiple indicators. Customer satisfaction was assessed on six items viz. call service, communication, price, facility, customer care, and service provider. Call service was evaluated by two items - call forwarding and waiting and service quality. Communication dimension was assessed by call quality, call drop rate and geographical coverage area. Facility factor was covered by items short message service, technology use, and mobile entertainment. Price factor was represented by items call rate, promotional offers and product range. Customer care comprising of complaint redressal system and complain resolution. Service provider factor constitute with the items - customer relationship, innovativeness, restoration capability, reliability and responsiveness. The data collected from questionnaires were analyzed by reliability Analysis and factor analysis. 


\section{Results and Discussion Reliability Coefficient}

Reliability coefficient tested by using Cronbach's alpha $(\alpha)$ analysis. In order to measure the reliability for a set of two or more constructs, Cronbach alpha is a commonly used method where alpha coefficient values range between 0 and I with higher values indicating higher reliability among the indicators (Hair, et al., 1992). In accordance with the Cronbach alpha test, the total scale of reliability for this study varies from 0.679 to 0.9778 indicating an overall higher reliability factors. The reliability of this study is substantial in every perspective, as the highest reliability value that can be achieved is I.0.

\begin{tabular}{|c|c|c|c|}
\hline \multirow{2}{*}{$\begin{array}{l}\text { Deviation } \\
\text { Communication (Alpha }=.9778 \text { ) }\end{array}$} & \multirow[t]{3}{*}{ Mean } & \multicolumn{2}{|c|}{ Std. } \\
\hline & & & \\
\hline Call quality & & 4.13 & 0.29 \\
\hline Call drop rate & & 4.03 & 1.04 \\
\hline Geographical coverage & 3.36 & 1.23 & \\
\hline \multicolumn{4}{|l|}{ Call service (Alpha $=.723$ ) } \\
\hline Call forwarding and waiting & & 2.36 & 0.94 \\
\hline Service quality & 3.97 & 0.89 & \\
\hline \multicolumn{4}{|l|}{ F acility (Alpha = .897) } \\
\hline Short message service & & 4.01 & 1.10 \\
\hline M obile entertainment & & 3.11 & 1.16 \\
\hline Technology use & 2.03 & 1.45 & \\
\hline \multicolumn{4}{|l|}{ Price factor (Alpha $=.967$ ) } \\
\hline Call rate & 4.36 & 0.89 & \\
\hline Promotional offers & & 4.00 & 1.10 \\
\hline Product range & & 3.76 & 0.88 \\
\hline \multicolumn{4}{|l|}{ C ustomer care (Alpha $=.679)$} \\
\hline Complaint redressal system & & 3.33 & 0.56 \\
\hline Complain resolution & & 3.45 & 0.90 \\
\hline \multicolumn{4}{|l|}{ Service provider (Alpha = .766) } \\
\hline Customer relationship & & 3.23 & 1.34 \\
\hline Innovativeness & & 3.46 & 1.44 \\
\hline $\begin{array}{l}\text { Restoration capability } \\
\text { Reliability }\end{array}$ & & 3.67 & 0.78 \\
\hline & & & \\
\hline Responsiveness & 3.73 & 0.45 & \\
\hline
\end{tabular}

\section{Factor Analysis}

The results obtained from $2 I 2$ respondents have been thoroughly analyzed. Using the statistical software package SPSS, factor analysis was carried out. The extraction method the principal component analysis (PCA) and verimax rotation were carried out to explore the underlying factors associated with 18 items. The constructs validity was tested applying Bartlett's Test of Sphericity and The Kaiser-Mayer-Olkin Measure of Sampling adequacy analyzing the strength of association among variables. The Kaiser-Mayer-Olkin measure of sampling adequacy (KMO) was first computed to determine the suitability of using factor analysis. It helps to predict whether data are suitable to perform factor analysis. $\mathrm{KMO}$ is used to assess which variables to drop from the model due to multicollinearity problem. The value of KMO varies from 0 to I, and KMO overall should be 0.60 or higher to perform factor analysis. If this does not have achieved, then it is necessary to drop the variables with lowest anti image value until KMO overall rises above .60 . Result for the Bartlett's Test of Sphericity and the KMO reveal that both were highly significant and concluded that this variable was suitable for the factor analysis (Table 3 ).

\begin{tabular}{|llr|}
\hline \multicolumn{3}{|l|}{ Kaiser - Meyer - Olkin Measure of Sampling Adequacy } \\
.911 & Approx. Chi-Square & 10043.963 \\
\hline \multirow{3}{*}{ Bartlett's Test of Sphericity } & df & 349 \\
& Sig. & .000 \\
\hline
\end{tabular}

Table $3 \mathrm{KMO}$ and Bartlett's Test

To determine the minimum loading necessary to include an item in its respective constructs, Hair et al. (1992) suggested that variables with loading greater than 0.30 is considered significant, loading greater than 0.40 more important, and loading 0.50 or greater are very significant. The result showed in table 4 .

Table 2 Reliability Analysis 


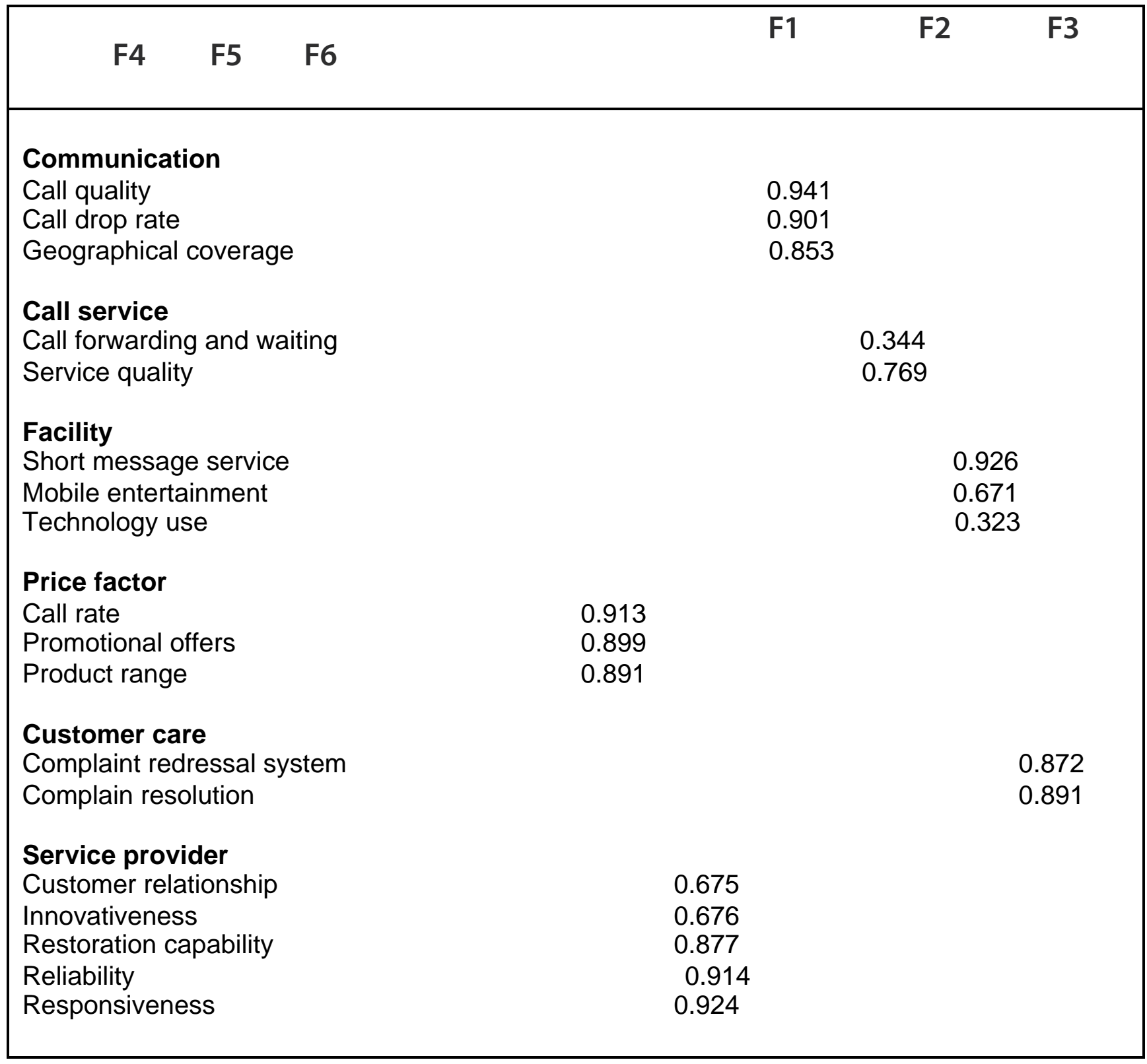

Table 4 Factor Matrices

From the factor analysis we can find that communication and price are the key and influencing factors that motivate the customers to prefer their service provider. Another factor that was found to influence preference of mobile service providers is the relationship it has with the customer which is determined by the promptness of response to the complaints and its how quicker it is resolved. The customers were evaluating customer care and service provider's corporate responsibility factors to select service providers. Respondents considered short messaging service as an impartment attributes, weightage for mobile entertainments was moderate and technology use was lower importance under facility factors. Only service quality has been considered and call forwarding and call waiting attributes of Call Service factors are not considered importance. 


\section{Conclusion}

This study was undertaken to examine and understand the consumers' perception choice in selecting cellular mobile telecommunication service providers. Consumers' perception is widely varied in accordance with the Communication quality, call service, facilities, price, customer care and service provider's quality. Hence, from the result of our study, we can deliberately conclude that price has significant positive impact on consumer perception choice in selecting telecommunication service provider. Hence, product quality from the marketer's perspective is associated with communication, price, feature, function, or performance of a product. Price plays a significant roll in the purchase decision of the telecommunications sector. However, our study shows that product quality and availability has a significant impact on consumer perception choice in selecting mobile telecommunication service provider and supported.

The outcome of this research shows a comprehensively integrated framework for us to understand the vibrant relationships among several dimensions of service quality, price, product quality and availability, and promotion to have handful ideas on the consumers' perception. However, we still predict that further research efforts are being needed to examine these factors with additional samples before generalization can be made.

\section{References}

COAI. (2009). Cellular Operators Association of India's report 2009. Cellular Operators Association of India. http:// www.coai.com/statistics.php (accessed June 19, 20II)

DANAHER, P.J, Mattsson, J. (1994). Customer Satisfaction during the Service Delivery Process. European Journal of Marketing, 28(5), 5-16.

DANAHER, P.J, Rust, R.T. (1996). Indirect Financial Benefits from Service Quality. Quality Management Journal, $3(2), 63-75$.

FORNELL, C. (1992). A National Customer Satisfaction Barometer: The Swedish Experience. Journal of Marketing, 56, 36-44.

GRONROOS, C.(1984).AServiceQualityModelanditsMarketing Implications. European Journal of Marketing, 18, 36-44.
HAFEEZ, S., Hasnu, S. (2010). Customer Satisfaction for Cellular Phones in Pakistan: A Case Study of Mobilink. Business and Economics Research Journal, I(3), 35-44.

HAQUE, A., Rahman, S., Rahman, M. (2010). Factors Determinants the Choice of Mobile Service Providers: Structural Equation Modeling Approach on Bangladeshi Consumers. Business and Economics Research Journal, I(3), 17-34.

KIM, M., Park, M., Jeong, D. (2004). The Effects of Customer Satisfaction and Switching Barrier on Customer Loyalty in Korean Mobile Telecommunication Services. Telecommunications Policy, 28,145-159.

LEE, J., Lee, J., Feick, F. (200I). The impact of the switching costs on the customer satisfaction-loyalty link: mobile phone service in France. Journal of Services Marketing, I5(I), 35-48.

LEHTINEN, U., Lehtinen, J.R. (199I). Two Approaches to Service Quality Dimensions. The Service Industries Journal, II(3), 287-305.

PARASURAMAN, A., Zeithaml, V.A., Berry, L. (1985). A Conceptual Model of Service Quality and its Implications for Future Research. Journal of Marketing, 49, 4I-50.

RANAWEerA, C., Neely, A. (2003). Some Moderating Effects on the Service Quality-customer Retention Link. International Journal of Operations \& Production Management, 23(2), 230-248.

RAPERT, M., Wern, B. (1998). Service Quality as a Competitive Opportunity. The Journal of services Marketing, 12(3), 223-235.

SETH, A., Momaya, K., Gupta, H. (2005). E-Service Delivery in Cellular Mobile Communication: Some Challenges and Issues. Global Journal of e-Business and Knowledge Management, 2(2), 30-42.

TROI. (2006). Study Paper on Financial Analysis of Telecom Industry of China and India - June 2006. Telecom Regulatory Authority of India, New Delhi, India.

TROI. (2010). The Indian Telecom Services Performance Indicators April - June 2010. Telecom Regulatory Authority of India, New Delhi, India. 